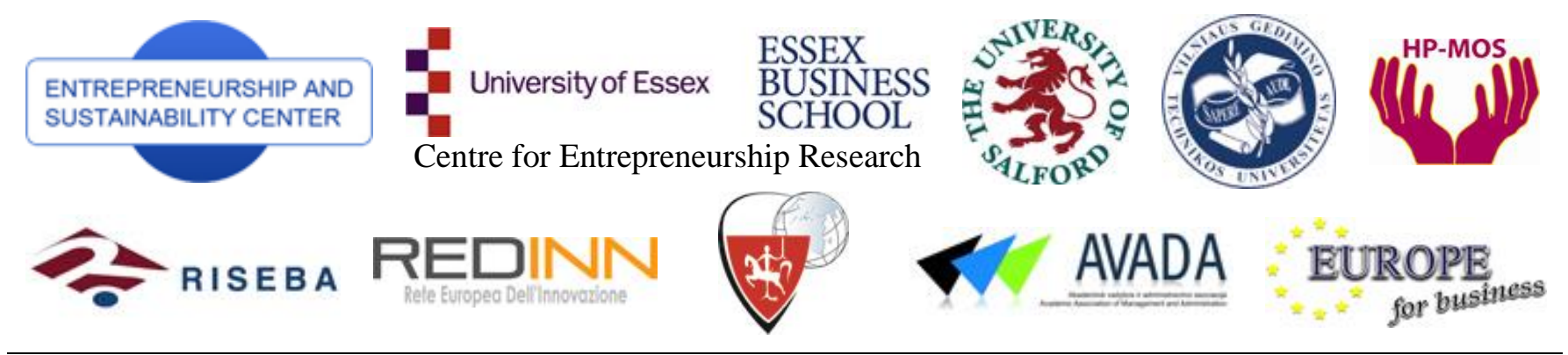

ENTREPRENEURSHIP AND SUSTAINABILITY ISSUES

ISSN 2345-0282 (online) http://jssidoi.org/jesi/aims-and-scope-of-research/

2013 Volume 1(2): 108-115

http://dx.doi.org/10.9770/jesi.2013.1.2(5)

\title{
SILENT ISSUES OF ICT ERA: IMPACT OF TECHNO-STRESS TO THE WORK AND LIFE BALANCE OF EMPLOYEES
}

\author{
Agota Giedrè Raišienè1, Steponas Jonušauskas² \\ ${ }^{1,2}$ Mykolas Romeris University \\ Ateities str. 20, Vilnius, Lithuania \\ E-mails: ${ }^{2}$ agotagiedre@gmail.com; ${ }^{2}$ steponas@bridge2apex.lt \\ Received 16 September 2013; accepted 6 November 2013
}

\begin{abstract}
The article aims to reveal the impact of techno-stress related to the usage of ICT on work and life balance of employees in Lithuania's organizations. The objectives of the research are twofold: to indicate the sources of techno-stress related to ICT usage at work in the Lithuania's organizations and to identify the impact of the issue on the work and life balance of employees. The paper presents an original research. The research is based on previous results of the analysis of computer mediated communication characteristics in Lithuanian organizations (Raisiene, Jonusauskas 2011; Raisiene 2012). Theoretical background of the given research is based on meta analysis and especially on the works of Tarafdar et al. (2011); Murray, Rostis (2007); Ayyagari et al. (2011); Park and Jex (2011). A questionnaire survey was applied for the empirical research. The survey was organized with the help of viral network, which involved social networks and chain e-mails. This method theoretically enables the whole researched population to take part. Method is useful due to its ability to reach significantly more representatives of different professions and sectors in a short period of time and with minimal resources in comparison to the method of sending questionnaires to particularly chosen organizations. The data of the empirical research was processed using a program SPSS Statistics. The results of the research reveal that employees in Lithuania are working under high techno-stress conditions that are formed by objective changes in global environment, organizations' leaders' attitude to ICT possibilities of increasing employee work efficiency, and by the behavior of the employees themselves. $75 \%$ of the employees are affected by technostress, and $41 \%$ of the respondents are suffering from work and life imbalance. It is necessary to critically appraise the benefits and disadvantages of life and work style, and to learn to better adapt in the environment of new technologies. It should be highlighted that a big part of this responsibility should be taken by the leaders of organizations. There were no preceding researches on employee technostress in Lithuania. It is hoped that the results of the research will make this important problem more relevant, as it has an influence on organizations' efficiency, people's life quality and development of healthy society.
\end{abstract}

Keywords: Techno-stress, work and life balance, Information and Communication Technologies, organization management, life quality, Lithuania.

Reference to this paper should be made as follows: Raišienė, A.G.; Jonušauskas, S. 2013. Silent issues of ICT era: impact of technostress to the work and life balance of employees, Entrepreneurship and Sustainability Issues 1(2): 108-115.

http://dx.doi.org/10.9770/jesi.2013.1.2(5)

JEL Classifications: M10, M15 


\section{Introduction}

Modern variety of information communication technologies (further in the text - ICT) enables the employees to accomplish their assignments independently of time and place, adjust their personal life and work related commitments. Despite of undisputed benefits of ICT, more and more scientists who examine the factors of organizational effectiveness and employee efficiency warn that techno-stress has a negative impact on employee well-being and work motivation, causes health problems and reduces performance. Scientific literature refers to this sort of tension as techno-stress (Ayyagari et al. 2011). It is a fact that the penetration of modern information and communication technologies is especially active in Lithuania and people widely use ICT for personal needs.

Considering this fact, an assumption could be made that the society has a positive attitude to ICT. The majority of the society is able to perceive the innovations of ICT relatively fast and feel confident about using their advantages. Does this mean that employees of Lithuanian organizations, who intensively use ICT to accomplish their work assignments undergo less stress, maintain high efficiency and coordinate work and leisure time better, compared to the situation in western countries? This question describes the problem of the scientific research analyzed in this article. The objectives of the research were twofold: to indicate the sources of techno-stress related to ICT usage at work in the Lithuania's organizations and to identify the impact of issue to the work and life balance of employees. The article consists of four parts. The first part discusses the effect of techno-stress. The second part presents the conceptual framework of the research. The methodology of the empirical research is introduced in detail in the third part. Fourth part of the research discusses the results of the research and forms insights. Conclusions are given at the end of the article.

\section{Effect of techno-stress on the individual}

The term "techno-stress" was first introduced by a psychologist Craig Brod in the year 1984, in his book "Techno-stress: the price of computer revolution for a human". The author defined techno-stress as a modern health disorder, rising from an individual's incompetence to rationally adapt in an environment filled with technologies (Brod 1984). Researcher Champion (1988) highlights, that techno-stress is a serious health problem, which is accompanied by panic, anxiety, resistance to innovations and leader's orders, techno-phobia, mental fatigue, physical ailments, tightened boundaries of tolerance, perfectionism. In addition, later researches approved that communication with the help of technologies increases the negative stress felt by the communicating individuals. One of such researches was carried out by Barley et al. (2001), who investigated the growth of interpersonal communication technology usage and the consequences that follow it. Assessed overall, techno-stress is considered as a negative phenomenon. What causes it and what are its consequences? Through informational technologies, the employees can easily and quickly reach the information needed for work, work out of office and share insights with colleagues real-time. Unfortunately, technologies make workers feel dependent on the constant connection with others more and more. Nevertheless, following processes could be called "communication" only relatively because necessity to make a lot of extra decisions. This necessity arises when workers wish to react to work information that is flowing in a constant stream on time. Finally, the conditions of intense communication leave no time to think over and discuss ideas.

In the previous decade, a research carried out by $\mathrm{Tu}$ et al. (2005) showed that the most obvious symptom of techno-stress is a decrease in work efficiency. Researches of Tarafdar et al. (2010) reveal that techno-stress negatively affects individual's cognitive abilities, e.g. the ability to make decisions, and finally leads to unsatisfactory work results. Furthermore, scientists who analyzed direct users of computers noticed, that factors generating techno-stress lead to a plunge in work satisfaction, which in turn determines a weakening in dedication to the organization (Ragu-Nathan et al. 2008). Conner (2012) states that feeling of deteriorated memory, impatience to others, increasing inability to rest, dizziness, apetite and digestion disorders, back pains, increased heart rhythm and troubled sleep is determined by a quick life pace, which is typical nowadays, not necessarily by the use of technologies. However, the author also notes that technologies that are designed to ease the troubles of work and house-chores did not reduce tension, but instead enabled people to plan additional activities and accept more duties. In conclusion, techno-stress is a problem arising from daily and intense use of technology, which has a negative effect on the employees' health, work efficiency and life quality. 


\section{Research conceptual framework}

Theoretical background of the given research is based on meta analysis and especially on the works of Tarafdar et al. (2011), Murray and Rostis (2007), Ayyagari et al. (2011), and Park and Jex (2011). Tarafdar et al. (2011) is the most cited author. He reported assumptions of techno stress which are techno-overload, techno-invasion, techno-complexity, techno-insecurity and techno-uncertainty. Further these factors are briefly discussed:

- Techno-overload. ICT creates the impression that professionals can work more and faster when using it. In other words, the staff feels the pressure to accomplish more in less time. Globalization and competitive nature of business composed "scared" organizations which are based on the principle of rewarding people who work exceptionally hard and spend much more hours at work in comparison with others (Ayyagari et al. 2011).

- Techno-invasion. Thanks to ICT, workers are potentially accessible everywhere and at any time. Organizations use this technology feature widespread. A prevailing attitude in business environment is that modern staff should be compassionate and employees must ensure that they will be accessible all the time, because competitive organizations must function without interruption. Employees are bombarded with ICT, and experiencing intervention in their personal space and time. So work-life imbalance can be seen not only as a cause of stress, but also as an outcome. For example, Murrary and Rostis (2007) study showed that e-mail, mobile phones and other mobile devices cause stress, and make it easier for work to invade the individual time and life of a person. When the boundaries between work and non-work are blurred, the quality of life declines, as well as the employee productivity. Research of work and family time overlap done by Park and Jex (2011) showed that the perpetual presence of an employee „on-line“ causes annoyance to the person, because he cannot focus enough on the family, household or recreation. Personal issues of employee are often set aside during working day. On the other hand, it is the reason, why the employees arrange family vacation and leisure, communicate with friends, taking a look to daily press online and so on at the work place. During and after the work day the employees are torn between personal and working matters. Van Steenbergen et al. (2009), Peeters et al. (2013), Park and Jex (2011) have confirmed that overlapping of work and family affairs triggers various tensions, and also causes emotional exhaustion, depression, dissatisfaction with work and life in general.

- Techno-complexity. Complexity of organizational information system is forcing practitioners to periodically take the time and effort for learning how to use new and updated technologies. Employees begin to feel tension because they can neither avoid the increased workload associated with additional learning nor regulate the volume of learning.

- Techno-insecurity. It occurs in situations where employees feel threatened of losing their jobs, due to the co-workers having better mastered the new technology. It is quite normal that new, often younger staff is coming into the organization due to having a higher level of technological knowledge.

- Techno-uncertainty. Professionals may feel that they do not have enough experience in the field because of continuous organizational and technological change. Employees feel anxiety because they find that their knowledge is becoming outdated very quickly.

Some authors also argue that techno stress might not have a very negative impact on the quality of employees personal life only in the case of absence of psychological pressure used by managers to proceed parallel with multiple technologies in daily work of employees (Çoklar and Sahin 2011).

In conclusion, it could be emphasized that the technology provides a global business freedom, but it is almost impossible to "disconnect" from the problems of work, to have clear work-and-life boundaries, which is essential to maintain good personal health. Organizations' managers have the expectation that employees understand the business challenges of the new era and are willing to make a sacrifice in the name of the organizations' achievements. 


\section{Research methodology and socio-demographic data of the respondents}

A questionnaire survey was applied for the empirical research. The survey was organized with the help of viral network, which involved social networks (Facebook, LinkedIn) and chain e-mails. This method theoretically enables the whole researched population to take part. Method is useful due to its ability to reach significantly more representatives of different professions and sectors in a short period of time and with minimal resources in comparison to the method of sending questionnaires to particularly chosen organizations. The data of empirical research was processed using a program SPSS Statistics.

Survey population was unknown. Theoretically, ICT can be used by all Lithuanian workers. Based on this premise the study population is composed of approximately 1,272 million (Statistics Lithuania 2013). According to simple random sampling methodology a representative population should consist of a minimum of 384 respondents (for 95\% reliability). 395 properly completed questionnaires were received. Table 1 presents the socio-demographic data of respondents.

Table 1. Socio-demographic data of the respondents

\begin{tabular}{|l|l|l|l|l|}
\hline No. & Category & Variant & Frequency & Percent \\
\hline 1. & All respondents & All respondents & 395 & 100 \\
2. & Gender & Female & 291 & 73,7 \\
& & Male & 104 & 26,3 \\
& & $<30$ & 126 & 31,9 \\
& & $30-39$ & 124 & 31,4 \\
4. & Education & $40-49$ & 87 & 22,0 \\
& & $50-59$ & 50 & 12,7 \\
5. & Represented sector & $>60$ & 8 & 2,0 \\
& & Secondary education & 7 & 1,8 \\
& & College & 21 & 5,3 \\
6. & Role at organization & Privater education & 367 & 92,9 \\
& & Public & 178 & 45,06 \\
& & NGO & 191 & 48,36 \\
& & Other & 7 & 1,77 \\
& & Manager & 72 & 4,81 \\
& & Specialist / administration & 305 & 18,2 \\
& & staff & 16 & 77,2 \\
\hline
\end{tabular}

Source: authors

Respondents were offered a closed type questionnaire. The questioned were asked to express their opinion by choosing one of five answers: Strongly agree, agree, neither agree nor disagree, disagree and strongly disagree. To analyze the results, answers were evaluated using Likert's (total evaluation) scale, where the answer "Strongly agree" was evaluated by 5 points and "Strongly disagree" was evaluated by 1 point.

The research questionnaire was composed of eight segments: 1. ICT in the organization. Questions were given to find out the nature of ICT change in organizations and the importance of ICT for organizing the employees" work and collaboration; 2. Properties of assignment organization and accomplishment. The questions in this segment were meant to ascertain how intensively is ICT used by employees while performing their tasks; 3 . ICT and personal time. Questions were formed that allowed to evaluate the harmony (and its possibilities) between employees' personal and work life; 5. Dependency on ICT. The questions were given with a goal to identify if the organizations' employees have a choice of work medium and tools and opportunity to decide whether to accomplish the daily work assignments with or without using ICT; 6. ICT and self-consciousness. In this segment, respondents were asked to describe their physical, psychological and emotional state and typical behavior that, according to the respondents, is related with the use of ICT to accomplish daily assignments; 7. 
Satisfaction in work and personal life. These questions were used to find out how respondents evaluate their work and personal life quality, health condition, resources of inner energy; 8. Common information. Respondents were asked to identify their age, gender, education, branch of activity of their represented organization etc.

This article presents only those research results that reveal the specifics of ICT usage in organizations and allows to describe the aspect of employees' work and personal life balance. All the data of the research is being prepared for publishing in a special science study.

\section{Research results}

Research data shows that employees intensively use ICT to accomplish their daily work commitments (Table 2). Almost 80 per cent of the questioned marked that their work process is very tense, due to the need of communicating and executing tasks using several ICT channels and tools at the same time. Only 5.6 per cent of the respondents claimed that their work routine is not tense. Assignment overlap is typical for the work of research participants as well. 73.4 per cent of the respondents emphasized not being able to unambiguously identify the end of one assignment and the start of a new one, due to executing multiple tasks in parallel. In addition, 70.4 per cent of the questioned state that they need to work more quickly in order to cope with the amount of assignments.

Table 2. Intensity of ICT use for accomplishing daily work assignments

\begin{tabular}{|c|c|c|c|c|c|c|}
\hline Respondents' answers & $\begin{array}{l}\text { Strongly agree, } \\
\% \text { (Frequency) }\end{array}$ & $\begin{array}{l}\text { Agree, } \\
\% \text { (Frequency) }\end{array}$ & $\begin{array}{l}\text { Neither agree } \\
\text { nor disagree, } \% \\
\text { (Frequency) }\end{array}$ & $\begin{array}{l}\text { Disagree, \% } \\
\text { (Frequency) }\end{array}$ & $\begin{array}{l}\text { Strongly } \\
\text { disagree, \% } \\
\text { (Frequency) } \\
\end{array}$ & \multirow{3}{*}{$\begin{array}{l}\text { Evaluation of } \\
\text { stressor, } \\
\%, \text { (points) }\end{array}$} \\
\hline Evaluation points & \multirow[t]{2}{*}{5} & \multirow[t]{2}{*}{4} & \multirow[t]{2}{*}{3} & \multirow[t]{2}{*}{2} & \multirow[t]{2}{*}{1} & \\
\hline $\begin{array}{l}\text { Factors determining techno- } \\
\text { stress (stressors) }\end{array}$ & & & & & & \\
\hline $\begin{array}{l}\text { Working with several ICT tools } \\
\text { at the same time }\end{array}$ & $43,3(171)$ & $36,5(144)$ & $14,7(58)$ & $4,8(19)$ & $0,8(3)$ & $83,4(4,17)$ \\
\hline $\begin{array}{l}\text { Task overlapping, difficulties } \\
\text { identifying work beginning and } \\
\text { end }\end{array}$ & $34,2(135)$ & $39,2(155)$ & $17,0(67)$ & $9,1(36)$ & $0,5(2)$ & $79,4(3,97)$ \\
\hline $\begin{array}{l}\text { Necessity to work quicker due } \\
\text { to increase workload }\end{array}$ & $27,6(109)$ & $42,8(169)$ & $22,0(87)$ & $7,1(28)$ & $0,5(2)$ & $78,0(3,90)$ \\
\hline Work overloads & $17(67)$ & $31,6(125)$ & $30,1(119)$ & $19,0(75)$ & $2,3(9)$ & $68,4(3,42)$ \\
\hline
\end{tabular}

Source: authors

Having analyzed the employees' medium of task execution and the possibility its choice, it was found out that nowadays employees are significantly dependent on ICT. Without ICT they would not be able to fulfill the majority of their commitments, receive and deliver information, communicate (Table 3). The research data shows that 85.6 per cent of the questioned execute particular tasks obligatory in their organization's internal network (e.g. filling reports, prepare and deliver documents etc.). In addition, 76.5 per cent of the research participants claimed that the inner network of the organization includes a catalogue of shared documents that is available and mandatory to use by all organization's employees. On a tight scale, tasks in organization's informational system are only executed by 5.4 per cent of the respondents. It is important to emphasize that the respondents are not able to think of any alternative medium for executing tasks. 94.1 per cent of them state that ICT has become a compulsory daily work medium and tool. 88.1 per cent of the questioned could not work without a computer. Employees' interpersonal and intergroup communication also usually takes place in the virtual space. This statement was essentially supported by almost 67 per cent of the research participants. As it is obvious from the research results, employees ' dependence on technologies is very strongly expressed. During the research, respondents were asked about their attitude to the alternation of informational communication technologies in their represented organizations. A question was given whether the programs and hardware used by employees were updated often. 
Table 3. Dependence on ICT for accomplishing direct responsibilities

\begin{tabular}{|c|c|c|c|c|c|c|}
\hline Respondents' answers & $\begin{array}{l}\text { Strongly agree, } \\
\% \text { (Frequency) }\end{array}$ & $\begin{array}{l}\text { Agree, } \\
\text { \% (Frequency) }\end{array}$ & $\begin{array}{l}\text { Neither agree } \\
\text { nor disagree, } \\
\% \text { (Frequency) }\end{array}$ & $\begin{array}{l}\text { Disagree, \% } \\
\text { (Frequency) }\end{array}$ & $\begin{array}{l}\text { Strongly } \\
\text { disagree, \% } \\
\text { (Frequency) }\end{array}$ & \multirow{3}{*}{$\begin{array}{l}\begin{array}{l}\text { Evaluation of } \\
\text { stressor, }\end{array} \\
\% \text { (points) }\end{array}$} \\
\hline Evaluation points & \multirow[t]{2}{*}{5} & \multirow[t]{2}{*}{4} & \multirow[t]{2}{*}{3} & \multirow[t]{2}{*}{2} & \multirow[t]{2}{*}{1} & \\
\hline $\begin{array}{l}\text { Factors determining techno- } \\
\text { stress (stressors) }\end{array}$ & & & & & & \\
\hline $\begin{array}{l}\text { Wide scale of task execution with } \\
\text { the help of ICT }\end{array}$ & $43,3(171)$ & $42,3(167)$ & $9,1(36)$ & $4,1(16)$ & $1,3(5)$ & $84,4(4,22)$ \\
\hline $\begin{array}{l}\text { High volume of electronic } \\
\text { documentation }\end{array}$ & $37,5(148)$ & $39(154)$ & $10,9(43)$ & $8,4(33)$ & $4,3(17)$ & $79,4(3,97)$ \\
\hline Lack of alternatives to ICT usage & $63(249)$ & $31,1(123)$ & $3,5(14)$ & $2(8)$ & $0,3(1)$ & $91(4,55)$ \\
\hline $\begin{array}{l}\text { Task execution with the help of a } \\
\text { computer }\end{array}$ & $58,2(230)$ & $29,9(118)$ & $7,6(30)$ & $3,8(15)$ & $0,5(2)$ & $88,4(4,42)$ \\
\hline $\begin{array}{l}\text { Transferring communication } \\
\text { processes into virtual space }\end{array}$ & $25,3(100)$ & $41,5(164)$ & $17,7(70)$ & $14,4(57)$ & $1(4)$ & $75,2(3,76)$ \\
\hline
\end{tabular}

Source: authors

In addition, the respondents were asked to evaluate the need of constantly and often renewing their knowledge in order to effectively use the advantages of updated ICT. The distribution of respondents ${ }^{6}$ answers is presented by Table 4. According to the data of the research, a statement could be made that Lithuanian organizations use the most modern innovative ICT. This statement was supported by 75.6 and denied by 11.4 per cent of the respondents. To sum up, Lithuanian organizations update ICT often and change them to newer versions and improved products. This conclusion is grounded by the support of 63.3 per cent of the questioned, who claimed that employees have to constantly supplement their ICT knowledge, as without improvement they would not be able to accomplish their responsibilities. Only 12.7 per cent of the employees do not think that persistent learning is irrelevant.

Table 4. Pace of ICT alternation

\begin{tabular}{|c|c|c|c|c|c|c|}
\hline Respondents' answers & $\begin{array}{l}\text { Strongly agree, } \\
\% \text { (Frequency) }\end{array}$ & $\begin{array}{l}\text { Agree, } \\
\% \text { (Frequency) }\end{array}$ & $\begin{array}{l}\text { Neither agree } \\
\text { nor disagree, } \\
\% \text { (Frequency) }\end{array}$ & $\begin{array}{l}\text { Disagree, \% } \\
\text { (Frequency) }\end{array}$ & $\begin{array}{l}\text { Strongly } \\
\text { disagree, \% } \\
\text { (Frequency) }\end{array}$ & \multirow{2}{*}{$\begin{array}{l}\text { Evaluation of } \\
\text { stressor, } \\
\% \text {, points) }\end{array}$} \\
\hline Evaluation points & 5 & 4 & 3 & 2 & 1 & \\
\hline $\begin{array}{l}\text { Periodicity of ICT updates: use } \\
\text { of innovative ICT }\end{array}$ & $34,6(138)$ & $41(162)$ & $12,7(50)$ & $10,1(40)$ & $1,3(5)$ & $79,6(3,98)$ \\
\hline $\begin{array}{l}\text { Necessity of ICT knowledge } \\
\text { updating and perfecting in } \\
\text { order to accomplish simple } \\
\text { assignments }\end{array}$ & $12,2(48)$ & $51,1(202)$ & $24,1(95)$ & $12,2(48)$ & $0,5(2)$ & $72,4(3,62)$ \\
\hline
\end{tabular}

Source: authors

The potential risk of techno-stress is significantly influenced by employees ' personal characteristics. Individuals who are confident in their abilities of coping with difficulties arising when executing tasks have higher learning motivation and are able to actually apply ICT innovations in their work. These people undergo considerably less techno-stress than individuals who are characterized with lesser self-confidence and self-discipline. The research results have shown that only a mediocre self-confidence is typical to the survey participants. Individual behavior is especially important to consider when talking about employees ' techno-stress. Coordinating and balancing work and rest should be an employees' responsibility and choice. Unfortunately, the research has shown that work and rest regime is only concerned by less than half of the employees (Table 5). 41.5 per cent of the respondents admitted constantly working with the help of ICT after work hours and on weekends. 47.3 per cent of the questioned do not use ICT tools for work in their leisure time. And another 11.1 per cent claimed only 
sometimes working after work from home. Sacrificing personal time for work reduces the employees' possibility to recover strength, have enough rest from work assignments both psychologically and physically. Moreover, it harms the employees' life quality and their work efficiency. This assumption is supported by the respondents ${ }^{6}$ evaluation of inner energy and time dedicated to communication with family and friends. Respectively 44,41 and 44 per cent of the questioned are partly dissatisfied or dissatisfied with the discussed fields of selfconsciousness and personal life. In addition, one fifth (respectively 22, 20 and 20 per cent) of the respondents are only partly satisfied by these fields.

Table 5. Individual behaviour and self-confidence

\begin{tabular}{|c|c|c|c|c|c|c|}
\hline Respondents' answers & $\begin{array}{l}\text { Strongly } \\
\text { agree, } \\
\% \\
\text { (Frequency) }\end{array}$ & $\begin{array}{l}\text { Agree, } \\
\% \text { (Frequency) }\end{array}$ & $\begin{array}{l}\text { Neither } \\
\text { agree nor } \\
\text { disagree, \% } \\
\text { (Frequency) }\end{array}$ & $\begin{array}{l}\text { Disagree, } \\
\% \text { (Frequency) }\end{array}$ & $\begin{array}{l}\text { Strongly } \\
\text { disagree, } \\
\% \text { (Frequency) }\end{array}$ & \multirow{2}{*}{$\begin{array}{l}\begin{array}{l}\text { Evaluation of } \\
\text { stressor }\end{array} \\
\% \text { (points) }\end{array}$} \\
\hline $\begin{array}{l}\text { Factors determining techno- } \\
\text { stress (stressors) }\end{array}$ & 5 & 4 & 3 & 2 & 1 & \\
\hline $\begin{array}{l}\text { Imbalanced work and leisure } \\
\text { time }\end{array}$ & $19,2(76)$ & $22,3(88)$ & $11,1(44)$ & $28,1(111)$ & $19,2(76)$ & $58,8(2,94)$ \\
\hline $\begin{array}{l}\text { Wide scale of usage of ICT } \\
\text { benefits }\end{array}$ & $4,6(18)$ & $27,3(108)$ & $29,1(115)$ & $33,2(131)$ & $5,8(23)$ & $58,3(2,92)$ \\
\hline
\end{tabular}

Source: authors

The respondents have also claimed that they feel inspiration or the wish to be enterprising increasingly rarer. This statement was supported by 34 per cent of the respondents, whereas 33 per cent chose the answer "sometimes". A statistically reliable relation of medium strength was found between unbalanced work and leisure time and employees" inner energy resources $\left(\mathrm{r}_{\mathrm{S}}=.569, \mathrm{p}<0,01\right)$. Work and rest balance factors strongly correlate with a possibility to dedicate time for communicating with family $\left(\mathrm{r}_{\mathrm{S}}=.793, \mathrm{p}<0,01\right)$ and have a medium correlation with the possibility to communicate with friends $\left(\mathrm{r}_{\mathrm{S}}=.606, \mathrm{p}<0,01\right) \quad$ (Table 6$)$.

Table 6. Correlation between the respondents' satisfaction in work-and-rest balance and an opportunity to dedicate enough time for communication with family and friends

\begin{tabular}{|l|c|r|r|r|}
\hline & Spearman's rho & $\begin{array}{c}\text { Possibility to dedicate } \\
\text { time for communication } \\
\text { with family }\end{array}$ & $\begin{array}{c}\text { Possibility to } \\
\text { communicate with } \\
\text { friends }\end{array}$ & $\begin{array}{c}\text { Satisfaction in one's } \\
\text { inner energy resources }\end{array}$ \\
\hline $\begin{array}{l}\text { Satisfaction in the balance of } \\
\text { work and leisure time }\end{array}$ & $\begin{array}{c}\text { Correlation } \\
\text { Coefficient } \\
\text { Sig. (2-tailed) }\end{array}$ &, $793^{* *}$ &, $606^{* *}$ &, $569^{* * *}$ \\
& $\mathrm{~N}$ & 390 &, 000 & 395 \\
\hline
\end{tabular}

**. Correlation is significant at the 0.01 level (2-tailed)

Source: authors

While summing up all the data of the empirical research, it was found that most of the techno stressors were evaluated as distinctly expressed. It is obvious that employees are undergoing high techno-stress while executing everyday tasks, which negatively affects their efficiency and quality of personal life.

\section{Conclusions and implications for the practice}

An empirical research has shown that the Lithuanian workers face with constant techno stress, resulting from: global environmental change, namely, inter-organizational and interpersonal competition and technological development speed; the managers' attitude towards ICT capabilities of enhancing employee performance; and behavior of the employees themselves. 
Conditions for negative effects of techno-stress for workers are favorable in Lithuania, because:

- ICT in organizations is widely applied in practically all areas of activity - from communicating, arrangement of documents to multi-tasking in organization's information system and customer service. Therefore, staff is strongly dependent on ICT all their working time. This means that such effective methods as task variety and job enrichment, can no longer keep employees' work efficiency up because the vast majority of the tasks must be carried out with ICT tools. Continuous and intensive involvement into the task's implementation is an assumption for emotional burnout. The Lithuanian workers live in a real danger of emotional burnout. This argument can be grounded by the fact that the majority of the respondents feel a decrease in the amount of internal energy and inspiration as well as a weaker willingness to be proactive. It is important to emphasize that as much as 75 percent of the surveyed employees notice that their work pace is slowing down in spite of using ICT only for their work in organizations.

- Employees experience the so called techno overload because of parallel work with several ICT tools. Due to the high amount of tasks employees feel psychological pressure to work faster and longer. Due to this reason, 52.6 percent of the staff continues to work from home in their personal time. 41.5 percent of respondents are practicing that constantly. This situation shows that the organization's managers have exaggerated expectations about ICT in relation to the increase in employee productivity. They lack work-flow planning skills and knowledge about the effects of stress on employability as well.

- When working after the working time, staff cannot devote sufficient time to their individual needs and personal liabilities. The study found a strong positive relationship between job satisfaction, work and life balance and the time allocated to the family. Moderate relationship was found between satisfaction with work and life balance and the time spent on maintenance of social relationships. Research also showed that employees who are using ICT intensively have less internal energy reserves. Thus, the study shows that ICT plays a role of a bridge and allows the work to break into the private lives of employees.

- In Lithuanian organizations, employees as well as employers and managers, lack knowledge on stress, as well as the awareness of taking care to maintain efficiency and to preserve health. When asked whether they work from home after work time, respondents mentioned that they do not work, only "handle work correspondence by e-mail", or "discuss the project issues with team members by phone" or "appoint a couple of hours for a calm review of reports", and so on. Employees do not understand that they are working! This paradox is caused by the mentality of work overestimation in Lithuania.

- ICT is evolving rapidly and changing substantially. This causes the so-called technological uncertainty. It is a situation where the technology is improving faster than the staff can become proficient in the use of additional or completely new ICT opportunities. Employees are forced to constantly feel insufficiently competent. In addition to technological uncertainty, workers' need to constantly take care of updating their knowledge on ICT. The techno-overload and imbalanced workload makes the phenomenon of techno-stress an inevitable part of daily life for workers.

It should be noted that techno-stress and decrease in performance, and work and life imbalance are caused not by the ICT itself, but by the human behavior while using ICT for work. Both employees and managers of organizations need to understand that ICT does not eliminate the need for employees to follow work and leisure regime. Especially managers need to be more responsible when planning organization's activities, and each individual employee's workload.

\section{References}

Ayyagari, R.; Grover, V.; Purvis, R. 2011. Technostress: Technological Antecedents and Implications, MIS Quarterly 35(4): 831-858.

Barley, S.R.; Grobal, S.; Meyerson, D.E. 2011. E-mail as a Source and Symbol of Stress, Journal of Organization Science 22(4): 887906.

Brod, C. 1984. Technostress: The human cost of the computer revolution. Boston, MA: Addison-Wesley.

Champion, S. 1988. Technostress: Technology's Toll, School Library Journal (November): 48-51. 
Çoklar, A.N.; Sahin, Y.L. 2011. Technostress Levels of Social Network Users Based on ICTs in Turkey, European Journal of Social Sciences 23(2): 171-182.

Conner, M. 2012. Technostress. A Sign of the Times, American Fitness 30 (4): 58-60.

Statistics Lithuania. 2013. Available on the <http://db1.stat.gov.1t/statbank/selectvarval/saveselections.asp?MainTable=M3010210\&PLanguage $=0 \&$ TableStyle $=\& B u t t o n s=\& P X S I d=$ 3239\&IQY=\&TC=\&ST=ST\&rvar0=\&rvar1=\&rvar2=\&rvar3=\&rvar4=\&rvar5=\&rvar6=\&rvar7=\&rvar8=\&rvar9=\&rvar10=\&rvar11=\&r $\operatorname{var} 12=\&$ rvar13=\&rvar14=>.

Murray, W.C.; Rostis, A. 2007. Who's running the machine? A theoretical exploration of work stress and burnout of technologically tethered workers, Journal of individual employment rights 12(3): 249-263.

Park, Y.; Jex, S.M. 2011. Work-Home Boundary Management Using Communication and Information Technology, International Journal of Stress Management 18(2): 133-152.

Peeters, M. C. W.; Ten Brummelhuis, L.: Van Steenbergen, E. F. 2013. Consequences of work-family interference: Consequences of Combining Work and Family Roles: A Closer Look at Cross-Domain Versus Within-Domain Relations, in Grzywacz, J. G. and Demerouti, E. (Eds.). New frontiers in work and family research.

Ragu-Nathan, T. S.; Tarafdar, M.; Ragu-Nathan, B. S.; TU, Q. 2008. The consequences of technostress for end users in organizations: Conceptual development and empirical validation, Information Systems Research 19(4): 417-433.

Raisiene, A.G. 2012. Restructuring Organization for Performance and Effectiveness: Applying Formal and Informal Electronic Communication Tool, Transformations in Business and Economics 2(26): 233-245.

Raišienè, A.G.; Jonušauskas, S. 2011. The usage of informal computer based communication in the context of organization's technological resources, Socialines technologijos: mokslo darbai [Social technologies: research papers] 1(2): 255-266.

Tarafdar, M.; TU, Q.; Ragu-Nathan, T.S. 2010. Impact of technostress on End-User Satisfaction and Performance, Journal of Management Information Systems 27(3): 303-334.

Tarafdar, M.; Tu, Q.; Ragu-Nathan, B.S.; Ragu-Nathan, T.S. 2011. Crossing to the Dark Side: Examining Creators, Outcomes, and Inhibitors of Technostress, Communications of the ACM 54(9): 113-120.

Tu, Q.; Wang, K.; Shu, Q. 2005. Computer-Related Technostress in China, Communications of The ACM 48(4): 77-81.

Van Steenbergen, E. F.; Ellemers, N.; Mooijaart, A. 2009. Combining work and family: How family supportive work environments and work supportive home environments can reduce work-family conflict and enhance facilitation, in Crane, D. R. and Hill, E. J. (Eds.). Handbook of Families \& Work. NY: University Press of America.

Dr. Agota Giedre Raisiene is an associate professor at Mykolas Romeris University, Lithuania. She is also a President of Management and Administration Academical Association, and a partner and business consultant in the JSC Bridge2Apex. Research interests: inter-sectorial and inter- organizational partnership, collaboration processes, decision-making in Public administration, organizational communication, computer mediated communication, social partnership.

Dr. Steponas Jonušauskas is a director at JSC Bridge2Apex, doctor of Physics and Mathematics, associated professor at Mykolas Romeris University, Lithuania. 